\title{
Toxoplasma gondii antibodies and related risk factors in mammals at Sorocaba zoo, São Paulo, Brazil
}

\section{Anticorpos anti-Toxoplasma gondii e fatores de risco em mamíferos do Zoológico de Sorocaba, São Paulo, Brasil}

\author{
Renata Bezerra Marujo ${ }^{2}$; Helio Langoni ${ }^{*}$; Leila Sabrina Ullmann²; Maysa \\ Pellizzaro ${ }^{2}$; Ramiro das Neves Dias Neto ${ }^{3}$; Lucilene Granuzzio Camossi ${ }^{2}$; Rodrigo \\ Friciello Teixeira ${ }^{3}$; Adauto Veloso Nunes ${ }^{3}$; Rodrigo Costa da Silva ${ }^{2}$; Benedito \\ Donizete Menozzi ${ }^{4}$
}

\begin{abstract}
Toxoplasmosis is a parasitic zoonosis with worldwide distribution and different wild species either are involved in maintenance of the pathogen in the environment as definitive or intermediate hosts serving as font of feeding or prey to definitive hosts. The present study aimed to investigate Toxoplasma gondii antibodies and the risk factors relating to infection in mammals at Sorocaba Zoo, state of São Paulo, Brazil. Serum samples collected from 153 animals were analyzed using the modified agglutination test (MAT; cutoff $\geq 25$ ). Seropositivity was found in 62 animals (40.5\%; 95\% CI: 33.1-48.5\%), with different titers. Significant differences were observed in relation to the ages of the animals, origin, presence of free-ranging animals in the enclosure and feeding habits, through univariate analysis $(p$ $\leq 0.05)$. Multivariate logistic regression analysis showed that only age $(p=0.03)$ had significance for the study. Adult animals were 3.5 more likely to become infected than were young ones. In relation to feeding habits, herbivores $(80 \%)$ and carnivores $(46.5 \%)$ were the animals most affected. These results highlight the presence of $T$. gondii in animals at Brazilian zoos, and suggest that continuous transmission is occurring at zoos.
\end{abstract}

Key words: Epidemiology. Toxoplasmosis. Wild animals. Zoo.

\section{Resumo}

Toxoplasmose é uma zoonose parasitária com distribuição mundial e diversas espécies silvestres estão envolvidas na manutenção do patógeno no ambiente, seja como hospedeiro definitivo ou intermediário. $\mathrm{O}$ objetivo do estudo foi pesquisar anticorpos de Toxoplasma gondii e os fatores de risco relacionados com a infecção de mamíferos do Zoológico de Sorocaba, Estado de São Paulo, Brasil. Foram coletadas 153 amostras de soro dos animais e realizado teste de aglutinação modificada (MAD, ponto de corte 16). Sessenta e dois (40,5\%; IC95\% 33,1-48,5\%) animais foram soropositivos, com diferentes títulos. Diferenças significativas foram observadas com relação a idade dos animais, origem, presença de animais de vida livre dentro dos recintos e hábitos alimentares, utilizando análise univariada $(\mathrm{p} \leq 0,05)$.

${ }^{1}$ Prof ${ }^{a}$, Universidade Estatual Paulista "Júlio de Mesquita Filho", UNESP, Botucatu, SP, Brasil. E-mail: hlangoni@fmvz.unesp.br

2 Discentes, UNESP, Botucatu, SP, Brasil. E-mail: renata.marujo@yahoo.com.br; leila_ullmann@yahoo.com.br; maysa. pellizzaro@fmvz.unesp.br; lucilenecamossi@gmail.com; silva_rcd@yahoo.com.br

3 Pesquisadores, Parque Zoológico Municipal Quinzinho de Barros, PZMQB, Sorocaba, SP, Brasil. E-mail: rdiaspa@yahoo.com. br,rhftzoo@hotmail.com; adautolvnunes@gmail.com

4 Pesquisador, UNESP, Botucatu, SP, Brasil. E-mail: benedito.dmenozzi@gmail.com

* Author for correspondence

Received: Nov. 22, 2016 Approved: May 08, 2017 
A análise pela regressão logística multivariada mostrou que apenas idade $(p=0.03)$ foi significativo no estudo. Animais adultos apresentaram 3,5 vezes mais chance de se tornarem infectados que os jovens. Com relação aos hábitos alimentares, animais herbívoros $(80 \%)$ e carnívoros $(46,5 \%)$ foram os mais afetados. Esses resultados ressaltam a presença do T. gondii nos animais dos zoológicos brasileiros e sugerem contínua transmissão no zoológico.

Palavras-chave: Epidemiologia. Toxoplasmose. Animais selvagens. Zoológico.

Wild animals, either in nature or in captivity, can be reservoirs for zoonosis. Adequate sanitary management is needed while keeping them in captivity, in order to decrease the incidence of disease transmission to them and to humans (SILVA et al., 2006). Toxoplasmosis is a worldwide zoonosis caused by the obligate intracellular parasite protozoon Toxoplasma gondii. Humans and other animals become infected by ingestion of sporulated oocysts that are shed in felids feces and/or ingestion of raw or undercooked meat containing bradyzoites or transplacental transmission (HILL et al., 2002). Many serological surveys have been conducted to evaluate the prevalence of toxoplasmosis among wild animals. However, there is scarce information about the role of different wild species and related risk factors in Brazilian zoos (FERREIRA et al., 1997; SILVA et al., 2001; GENNARI et al., 2004; GARCIA et al., 2005; SILVA et al., 2006; MINERVINO et al., 2010; ULLMANN et al., 2010). Accordingly, the aim of this study was to evaluate $T$. gondii infection in wild mammals at Sorocaba Zoo, SP, Brazil.

The Municipal Zoo Park “Quinzinho de Barros”, known as Sorocaba Zoo, occupies an area of 130,000 $\mathrm{m}^{2}$ and houses around 1,200 animals. A total of 153 animals living there were investigated for $T$. gondii antibodies, using the modified agglutination test (MAT; cutoff $\geq 25$ ), homemade formalin-fixed antigen (DESMONTS; REMINGTON, 1980; MORÉ et al., 2008). These animals were grouped according to their feeding habits, as follows. Omnivores: Ateles marginatus (6), Ateles chamek (1), Brachyteles arachnoides (4), Callithrix jacchus (5), Cebus xanthosternos (1), Erythrocebus patas (1), Didelphis albiventris (3), Didelphis aurita (5),
Didelphis marsupialis (9), Mandrillus sphinx (2), Papio hamadryias (6), Ursus americanus (1), Cebus olivaceus (1), Callithrix penicillata (1) and Pan troglodytes (1); carnivores: Cerdocyon thous (11), Chrysocyon brachyurus (3), Eira barbara (2), Felis catus (2), Leopardus pardalis (4), Leopardus tigrinus (15), Leopardus wiedii (1), Lycalopex vetulus (7), Nasua nasua (8), Panthera leo (3), Panthera onca (3), Panthera tigris tigris (1), Leopardus colocolo (1), Puma concolor (3), Herpailurus yagouaroundi (4) and Procyon cancryvorus (1); carnivores and piscivores: Lutra longicaudis (2); herbivores: Blastocerus dichotomus (1), Cervus elaphus (2), Elaphus maximus (1), Macropus fuliginosus (2), Mazama gouazoubira (1), Sphiggurus villosus (6) and Tapirus terrestris (3); frugivores: Alouatta guariba (3), Alouatta caraya (3) and Lagothrix lagothricha (3); and insectivores: Myrmecophaga tridactyla (9) and Tamandua tetradactyla (1). There were no complete data from some animals in zoo records, such as age, "origin", enclosure type and feeding habits.

MAT resulted in the finding that $62 / 153$ (40.5\%; 95\% CI: $33.1-48.5)$ of the animals were positive for $T$. gondii antibodies. This was considered to be lower than the proportion of $13 / 26(50 \%)$ that had been observed in a previous study in Brazil (VITALIANO et al., 2014), that used the same dilution. Table 1 shows the species with positive results, the number of specimens per species, their origin and the distribution of positive animals according to titer. In univariate analyses, significant associations were observed regarding age $(\mathrm{P}=$ $0.05)$, origin of the animals $(\mathrm{P}=0.01)$, feeding habits $(\mathrm{P}=0.00)$ and the presence of free-ranging wild animals in the enclosures $(\mathrm{P}=0.05)$. However, 
after the multivariate logistic regression analysis, of animals have been obtained with zoo register of only age was still considered significant $(\mathrm{P}=0.03)$ each individual.

(EpiInfo $^{\text {TM }}$ 7.1.5.2). All data about age and origin

Table 1. Toxoplasma gondii seropositive captive mammals from Sorocaba zoo (São Paulo, Brazil), categorized according to species, common name, origin (wild-caught/zoo born), number of specimens analyzed and distribution per titer.

\begin{tabular}{|c|c|c|c|c|}
\hline Species & Common Name & $\begin{array}{l}\text { Wild-caught/ } \\
\text { Zoo-born }\end{array}$ & $\begin{array}{c}\text { Number } \\
\text { of tested } \\
\text { animals }\end{array}$ & $\begin{array}{c}\text { Positive animals by titer } \\
16 / 64 / 256 / \geq 1,024\end{array}$ \\
\hline Ateles marginatus & White-fronted spider monkey & $0 / 5$ & 5 & $0 / 0 / 2 / 0$ \\
\hline Brachyteles arachnoides & Southern muriqui & $4 / 0$ & 4 & $0 / 0 / 0 / 1$ \\
\hline Cebus xanthosternos & Golden-bellied capuchin & $1 / 0$ & 1 & $0 / 0 / 0 / 1$ \\
\hline Pan troglodytes & Common chimpanzee & $0 / 1$ & 1 & $0 / 0 / 0 / 1$ \\
\hline Mandrillus sphinx & Mandrill & $0 / 2$ & 2 & $0 / 0 / 1 / 1$ \\
\hline Papio hamadryas & Hamadryas baboon & $0 / 6$ & 6 & $0 / 1 / 1 / 0$ \\
\hline Erythrocebus pata & Pata monkey & $0 / 1$ & 1 & $0 / 0 / 0 / 1$ \\
\hline Cerdocyon thous & Crab-eating fox & $7 / 4$ & 11 & $0 / 1 / 1 / 1$ \\
\hline Chrysocyon brachyurus & Maned wolf & $3 / 0$ & 3 & $0 / 3 / 0 / 0$ \\
\hline Lycalopex vetulus & Hoary fox & $4 / 3$ & 7 & $1 / 0 / 0 / 0$ \\
\hline Leopardus tigrinus & Oncilla & $11 / 4$ & 15 & $2 / 4 / 2 / 1$ \\
\hline Leopardus pardalis & Ocelot & $4 / 0$ & 4 & $0 / 1 / 1 / 0$ \\
\hline Panthera leo & Lion & $0 / 3$ & 3 & $1 / 2 / 0 / 0$ \\
\hline Panthera onca & Jaguar & $3 / 0$ & 3 & $1 / 1 / 1 / 0$ \\
\hline Puma concolor & Mountain lion & $2 / 1$ & 3 & $0 / 1 / 0 / 0$ \\
\hline Eira barbara & Tayra & $2 / 0$ & 2 & $0 / 2 / 0 / 0$ \\
\hline Lutra longicaudis & Neotropical otter & $2 / 0$ & 2 & $0 / 1 / 0 / 0$ \\
\hline Nasua nasua & South American coati & $5 / 3$ & 8 & $0 / 5 / 0 / 0$ \\
\hline Ursus americanus & American black bear & $0 / 1$ & 1 & $0 / 1 / 0 / 0$ \\
\hline Didelphis aurita & Big-eared opossum & $5 / 0$ & 5 & $0 / 0 / 1 / 0$ \\
\hline Didelphis marsupialis & Common opossum & $9 / 0$ & 9 & $0 / 0 / 1 / 0$ \\
\hline Macropus fuliginosus & Western gray kangaroo & $0 / 2$ & 2 & $0 / 0 / 0 / 2$ \\
\hline Sphiggurus villosus & South American porcupine & $0 / 6$ & 6 & $0 / 0 / 1 / 4$ \\
\hline Myrmecophaga tridactyla & Giant anteater & $5 / 4$ & 9 & $0 / 2 / 1 / 0$ \\
\hline Elaphus maximus & Asian elephant & $0 / 1$ & 1 & $0 / 1 / 0 / 0$ \\
\hline Cervus elaphus & Red deer & $0 / 2$ & 2 & $0 / 1 / 0 / 1$ \\
\hline Tapirus terrestris & South American tapir & $0 / 3$ & 3 & $0 / 2 / 1 / 0$ \\
\hline
\end{tabular}

Adult animals $(52 / 112 ; 46.4 \%$; 95\% CI: 37.5 $55.7 \%$ ) were 3.5 times more likely to become infected, in that environment, than younger ones (5/23; 21.7\%; 95\% CI: 9.8-42.2). This corroborates what was observed among mammals at Mexico City's zoo, where the prevalence also increased with age (ALVARADO-ESQUIVEL et al., 2013). Even though the variable "origin" was not significant in 
the multivariate analysis, visual differences could be seen. Zoo-born animals (32/58; 55.2\%; 95\% CI: $42.4-67.3 \%$ ) were 2.1 times more likely to present $T$. gondii antibodies than were wild-caught animals (30/91; 33\%; 95\% CI: $24.2-43.2 \%)$ in the same place. In a study conducted on felids, wildcaught animals were more likely to be positive than were zoo-born animals (ULLMANN et al., 2010). However, another study did not find any association relating to animal origin among animals in 20 Brazilian states (SILVA et al., 2007).

Animals kept in enclosures that facilitated entry of free-ranging wild animals (22/40; 55\%; 95\% CI: 39.8-69.3\%) were 2.2 more likely $(\mathrm{P}>0.05$, multivariate analysis) to be infected than were animals that lived indoors $(40 / 111 ; 36 \%$; $95 \% \mathrm{CI}$ : 27.7-45.3\%). This highlights the important role played by domestic cats and even synanthropic animals, such as rats, pigeons and opossums living close to the enclosures, over which there is no access control, with regard to transmission of this infection. Domestic cats have already been considered a risk factor for $T$. gondii infection in zoo animals. Moreover, ingestion of viable oocysts in the meat provided for feeding has also been considered a real risk in relation to infection of wild felids (SILVA et al., 2007).

Herbivores (12/15; 80\%; 95\% CI: 54.4-92.7\%), carnivores $(33 / 71 ; 46.5 \%$; 95\% CI: $35.3-58 \%)$, insectivores (4/11; 36.4\%; 95\% CI: $15.2-39.6 \%)$ and omnivores (12/47; $25.5 \%$; 95\% CI: $15.3-39.6 \%)$ presented the highest prevalences of $T$. gondii infection. For herbivores, the probable source of infection was the environment contaminated with oocysts due to presence of and access by cats and synanthropic animals to the enclosures. The prevalence among the carnivores in this study was similar what had previously been observed in the states of São Paulo and Mato Grosso, and in the Federal District of Brazil, among wild canids (50.5\%; 49/94) and felids $(63.4 \%$; 102/161) (ANDRE et al., 2010). The animals may have become infected either through environmental contamination or through consumption of parasite-harboring prey (ANDRE et al., 2010). Alternatively, it may have been due to the food management for those animals, such as lack of previous heat treatment for the meat that was provided from regularized distributors (SILVA et al., 2007).

The prevalence of toxoplasmosis of $48 \%$ observed among the felids (18/37) felids highlights the epidemiological importance of this class. Only felids excrete $T$. gondii oocysts, and they can be the source for environmental contamination as well as sentinels for infection of other species. Moreover, these results are similar to those previously reported in different Brazilian zoos (SILVA et al., 2001; ULLMANN et al., 2010). Nonetheless, two domestic cats that were caught in the zoo were found to be negative.

Although marsupials, Western gray kangaroos and New World primates are generally more susceptible to clinical toxoplasmosis (ALVARADOESQUIVEL et al., 2013), the seropositivity found in some of these animals indicates that some do survive infection (Table 1). In this study, the prevalence of $T$. gondii antibodies in giant anteaters (Myrmecophaga tridactyla) was $33.3 \%$ (3/9), which was lower than the in the first-ever report, in which the seropositivity was $100 \%(2 / 2)$ (VITALIANO et al., 2014). Additionally, 3/11 (27.3\%) of the Cerdocyon thous individuals were seropositive, with titers of 64, 256 and 1,024. This prevalence was lower than the findings from zoos in the states of São Paulo and Paraná (9/15, 60\%) (MINERVINO et al., 2010), but higher than the results from six zoos in the state of São Paulo (10/52, 19.2\%) (CATENACCI et al., 2010). In this last study, eight samples (15.4\%) presented titers of 16 and four of them $(50 \%)$ were from the same zoo. Two of these four animals were kept in the same enclosure, one in a neighboring enclosure and one in a somewhat distant enclosure. Neither of the $C$. thous individuals with higher titers (256 and 1,024) were bred in captivity. Both of them were adults and the enclosure allowed entry by other wild animals. To the author's knowledge, 
there had been no previous studies on C. thous. Nor were any high titers detected in the two animals at Sorocaba Zoo.

The high seropositivity shown by zoo mammals reflects their susceptibility to $T$. gondii infection due to entry of domestic cats and synanthropic animals into the enclosures and presence of contaminated environment, food and water, which act as risk factors for captive animals (ANDRE et al., 2010). It has been suggested that this prevalence is due to contaminated meat provided to animals. It is strongly recommended that meat for feeding carnivorous animals should firstly be frozen for at least seven days.

Thus, Toxoplasma infection is present in different wild species kept in the zoo studied here. Introduction of new animals into the zoo and the presence of synanthropic animals such as domestic cats need to be carefully observed and periodic monitoring with epidemiological surveys for prevalent zoonoses among wild animals is also necessary.

\section{References}

ALVARADO-ESQUIVEL, C.; GAYOSSODOMINGUEZ, E. A.; VILLENA, I.; DUBEY, J. P. Seroprevalence of Toxoplasma gondii infection in captive mammals in three zoos in Mexico City, Mexico. Journal of Zoo and Wildlife Medicine, Yulee, v. 44, n. 3, p. 803-806, 2013.

ANDRE, M. R.; ADANIA, C. H.; TEIXEIRA, R. H. F.; SILVA, K. F.; JUSI, M. M. G.; MACHADO, S. T. Z.; BORTOLLI, C. P.; FALCADE, M.; SOUSA, L.; ALEGRETTI, S. M.; FELIPPE, P. A. N.; MACHADO, R. Z. Antibodies to Toxoplasma gondii and Neospora caninum in Captive Neotropical and Exotic Wild Canids and Felids. The Journal of Parasitology, Lawrence, v. 96, n. 5, p. 1007-1009, 2010.

CATENACCI, L. S.; GRIESE, J.; SILVA, R. C.; LANGONI, H. Toxoplasma gondii and Leishmania spp. infection in captive crab-eating foxes, Cerdocyon thous (Carnivora, Canidae) from Brazil. Veterinary Parasitology, Dublin, v. 169, n. 1-2, p. 190-192, 2010.

DESMONTS, G.; REMINGTON, J. S. Direct agglutination test for diagnosis of Toxoplasma infection: method for increasing sensitivity and specificity. Journal of Clinical Microbiology, Washington, v. 11, n. 6, p.562568, 1980.

FERREIRA, R. A.; MINEO, J. R.; DUARTE, J. M.; SILVA, D. A. O.; PATARROYO, J. H. Toxoplasmosis in naturally infected deer from Brazil. Journal of Wildlife Diseases, Lawrence, v. 33, n. 4, p.896-899, 1997.

GARCIA, J. L.; SVOBODA, W. K.; CHRYSSAFIDIS, A. L.; MALANSKI, L. S.; SHIOZAWA, M. M.; AGUIAR, L. M.; TEIXEIRA, G. M.; LUDWIG, G.; SILVA, L. R. da; HILST, C.; NAVARRO, I. T. Sero-epidemiological survey for toxoplasmosis in wild New World monkeys (Cebus spp.; Alouatta caraya) at the Paraná River Basin, Paraná State, Brazil. Veterinary Parasitology, Dublin, v. 133, n. 4, p. 307-311, 2005.

GENNARI, S. M.; CANÓN-FRANCO, W. A.; YAI, L. E. O.; SOUZA, S. L. P. de.; SANTOS, L. C.; FARIAS, N. A. R.; RUAS, J.; ROSSI, F. W.; GOMES, A. A. B. Seroprevalence of Toxoplasma gondii antibodies from wild canids from Brazil. Veterinary Parasitology, Dublin, v. 121, n. 3-4, p. 337-340, 2004.

HILL, D.; DUBEY, J.P. Toxoplasma gondii: transmission, diagnosis and prevention. Clinical Microbiology and Infection, Tel-Aviv, v. 8, n. 10, p. 634-640, 2002.

MINERVINO, A. H.; SOARES, H. S.; BARRÊTOJUNIOR, R. A.; NEVES, K. A.; PENA, H. F.; ORTOLANI, E. L.; DUBEY, J. P.; GENNARI, S. M. Seroprevalence of Toxoplasma gondii in captive wild mammals and birds in Brazil. Journal of Zoo and Wildlife Medicine, Yulee, v. 41, n. 3, p. 572-574, 2010.

MORÉ, G.; BASSO, W.; BACIGALUPE, D.; VENTURINI, M. C.; VENTURINI, L. Diagnosis of Sarcocystis cruzi, Neospora caninum, and Toxoplasma gondii infections in cattle. Parasitology Research, Berlin, v. 102, n. 4, p. 5-671, 2008.

SILVA, A. V.; BOSCO, S. M. G.; LANGONI, H.; BAGAGLI, E. Study of Toxoplasma infection in Brazilian wild mammals: Serological evidence in Dasypus novemcinctus Linnaeus, 1758 and Euphractus sexcinctus Wagler, 1830. Veterinary Parasitology, Dublin, v. 135, n. 1, p. 81-83, 2006.

SILVA, J. C. R.; MARVULO, M. F. V.; DIAS, R. A.; FERREIRA, F.; AMAKU, M.; ADANIA, C. H.; FERREIRA NETO, J. S. Risk factors associated with seropositivity to Toxoplasma gondii in captive Neotropical felids from Brazil. Preventive Veterinary Medicine, Fort Collins, v. 78, n. 3-4, p. 286-295, 2007.

SILVA, J. C. R.; OGASSAWARA, S.; ADANIA, C. H.; FERREIRA, F.; GENNARI, S. M.; DUBEY, J. P.; FERREIRA-NETO, J. S. Seroprevalence of Toxoplasma 
gondii in captive neotropical felids from Brazil. Southern Brazil. Veterinary Parasitology, Dublin, v. 172 , Veterinary Parasitology, Dublin, v. 102, n. 3, p. 217-224, 2001.

n. 1-2, p. 144-146, 2010.

ULLMANN, L. S.; DA SILVA, R. C.; MORAES, W.; VITALIANO, S. N.; SOARES, H. S.; PENA, H. F. J.; CUBAS, Z. S.; SANTOS, L. C.; HOFFMANN, J. L.; MOREIRA, N.; GUIMARAES, A. M. S.; MONTAÑO, P.; LANGONI, H.; BIONDO, A. W. Serological survey of Toxoplasma gondii in captive neotropical felids from DUBEY, J. P.; GENNARI, S. M. Serologic evidence of Toxoplasma gondii infection in wild birds and mammals from southeast Brazil. Journal of Zoo and Wildlife Medicine, Yulee, v. 45, n. 1, p. 197-199, 2014. 